\title{
COOLING LOAD CALCULATIONS IN A MULTI-STORIED EDUCATIONAL BUILDING
}

\author{
A. Gogineni ${ }^{1 *}$, J. Apel ${ }^{1}$, S. B. Abdullah ${ }^{1}$, B. Pokhrel ${ }^{1}$ \\ 1* Assistant Professor, Saginaw Valley State University, 7400 Bay Road, University Center, Saginaw, MI, \\ 48710, USA, Email: agoginen@ @vsu.edu \\ ${ }^{1}$ Student, Saginaw Valley State University, Email: jsapel@svsu.edu \\ ${ }^{1}$ Student, Saginaw Valley State University, Email: sbinabdu@svsu.edu \\ ${ }^{1}$ Student, Saginaw Valley State University, Email: bpokhrel@svsu.edu
}

\begin{abstract}
This research was conducted to determine the indoor air flow throughout a multistory educational building. Due to increase in enrollments every year, classrooms are fully occupied which resulted in insufficient air flow in the classroom causing discomfort. This paper details numerous calculations to determine whether the multistory educational building's Heat Ventilation and Air Conditioning (HVAC) system was up to code by assessing the total amount of Cooling load and airflow, measured in Cubic Feet per Minute (CFM), within the building. The Cooling Load Temperature Difference (CLTD) method is a traditional method used while designing buildings HVAC system. Hence, the present study was conducted using the CLTD method to estimate the total cooling load and airflow in the building during summer season. The theoretical calculations were compared to measured values which showed difference in the airflow and cooling loads. The cooling load calculations measured in summer provided a dynamic approach to varying load and climate. The parameters assessed in the study include outside and room temperature, geographic position of building, occupancy, equipment, ventilation, etc. Fluctuations were noticed in the assessed parameters which affected the calculated CLTD load and CFM values in each room. The measured data was collected from the building's HVAC system to ensure the system was meeting the required demand of the load during the cooling season. The theoretical and measured data were compared for the summer season which shows that the Cooling loads and airflow within the building does not meets the building code standards for small classrooms.
\end{abstract}

KEY WORDS: CLTD, SLCF, CLF, HVAC.

\section{INTRODUCTION}

Prediction of cooling load, proper sizing and control of HVAC system minimizes the energy consumption in a building. Heat gain and CFM values are important factors in determining if the HVAC system is capable for handling cooling loads for the occupants in a multi-story educational building ${ }^{[1]}$. The CFM values of each room in the building will determine the right airflow necessary to create occupant comfort in the building. The present study is conducted in a multi-story educational building that has about 10 classrooms, 3 computer labs, 25 offices, 2 conference rooms, and 8 mechanical labs. The present study predicts the cooling loads, HVAC control and CFM values theoretically and compares them with experimental data. The theoretical calculations were conducted on several parameters considered from ASHRAE Cooling load standards. Some of the parameters include Heat gain, CFM, cooling load temperature difference, design heat transfer coefficient, etc. Heat gain is the transfer of heat into the building through a variety of sources such as sun shining through a window, lights, appliances, occupants, etc. The amount of heat gain can affect the 
airflow of the HVAC system if the system is not supplying enough cooling loads to balance the heat released by different sources. The CFM describes the capabilities of cooling and ventilation systems and it is the volume rate of air that flows within system. If the measured CFM value is not within the correct range, which is between 10-15 CFM per person, then actions must be taken to fix the problem. When the CFM values are not within the correct range the occupants can experience discomfort because there is not enough cool air being distributed within the room to account for all the occupants and appliances in the building. The key aspects necessary to maintain flow system inside the building are air quality, standard flow rates and sustainable energy consumption. To maintain these standards, Cooling Load Temperature Difference method (CLTD) is chosen for this project because of its low level of error and practical methodology for a small scaled project. Calculations are totally load dependent and the variation of the load will influence the calculated result of the experiment. The method of obtaining the CLTD and CLF used in this experiment were described in GRP 158 (ASHRAE 1979) and is based on work done by Rudoy and Duran (1975) ${ }^{[1]}$.

Extensive readings and research on similar experiments have been carried out by different authors. Elhelw.M conducted research at Alexandria University to compare distributions between the modified bin method and CLTD/SCL/CLF method ${ }^{[2]}$. Similarly, University of Tripoli's provided architects with a simple correlation for proper design of facades for office buildings using energy consumption. The work includes a case study, in which an external wall of a small office space located in the city of Tripoli, Libya was analyzed ${ }^{[3]}$. In this research, imperative factors, both external and internal that influence heating and cooling loads were examined. Energy consumption plays a major role in cooling loads, thus an overview of measures and policies adopted by different countries, allowing the monitoring, and reduction of the energy consumption in buildings were presented by allouhi.A et.al ${ }^{[4]}$. A study conducted at University of California shows that they used parametric computer simulations of single-family and multi-family residential building models to measure the contributions of building components such as roofs, walls, windows, infiltration, outside air, lighting, equipment, and people. They studied how these aspects added to the total heating and cooling loads in U.S. residential buildings, and the overall efficiencies of typical residential heating and cooling systems in meeting these loads ${ }^{[5]}$. A study similar to the present study shows

cooling load calculations for a spinning workshop using cooling load coefficient method and steady calculation method ${ }^{[6]}$. After conducting preliminary studies on the cooling load calculations in different buildings, the present study used CLTD method to perform theoretical calculations in multi-story education building and compare them with measured values to determine if the building's HVAC system is meeting the standards.

\section{METHODOLOGY \& ANALYTICAL PROCEDURE}

The cooling load calculations were conducted using the Cooling Load Temperature Difference/Cubic Feet/Minute (CLTD/CFM) method as described in the ASHRAE Fundamentals. The CLTD method requires indoor and outdoor temperatures, CFM, cooling load sources, equipment used in the building, heat gained by the equipment and occupancy rates. The cooling load sources based on the building include building details like roof, walls, glass, partitions, ceilings and floors. The classrooms, offices and laboratory floor plans were collected from the building maintenance office. For any flat wall or roof composed of layers of construction materials, including surface air films and internal air spaces, the ASHRAE Cooling Load Manual is followed, which has predetermined values for $U$, the coefficients of transmission for the building materials.

For standard calculations, the theoretical calculations were conducted by assuming climatic conditions from May to June between $6 \mathrm{am}$ to $6 \mathrm{pm}$ in the northern hemisphere. The outdoor temperatures were assumed based on the location and the details are given below.

Outdoor Design Conditions for Summer:

The building is located in Saginaw, the following table shows the climatic conditions for Saginaw in Michigan:

Table 1 Climatic conditions for Saginaw, Michigan ${ }^{[7]}$

\begin{tabular}{|c|c|c|c|}
\hline \multirow{2}{*}{ Saginaw } & \multicolumn{3}{|c|}{ Design Wet-Bulb Temperature $\left({ }^{\circ} \mathrm{F}\right)$} \\
\cline { 2 - 4 } & $1 \%$ & $2.5 \%$ & $5 \%$ \\
\hline
\end{tabular}


Several parameters like CLTD, Cooling Load Factor (CLF), shade coefficients (SC) were used as part of the calculations in determining the cooling load for several segments in a building which were taken from ASHRAE Manual ${ }^{[7]}$. Table 2 of the Manual provides the details of the sources, equations and reference numbers from the Handbook ${ }^{[7]}$.

Heat gain

Heat gain refers to the rate at which heat is transferred into or generated inside a building. Heat gain is separated into sensible and latent heat gains that can occur through conduction, convection, and radiation. The latent heat gain is the cooling load whereas sensible heat gain depends on the characteristics of the space. Thermo-physical properties of walls, floors, ceilings, and windows, lighting power density (LPD), plug load density, occupant density, and equipment efficiency play an important role in determining the magnitude of heat gains in a building ${ }^{[8]}$.

Table 2 Procedure for calculating space design cooling load - summary of load sources and equations. ${ }^{[7]}$

\begin{tabular}{|c|c|c|}
\hline Cooling Load Source & Equation & References, Table, Description \\
\hline External & $q=U \times A \times C L T D$ & $\begin{array}{l}\text { U values from Table } 3.1-3.5 \\
\text { Area calculated from plans } \\
\text { Cooling Load Temperature Difference (CLTD) } \\
\text { rom tables } 3.8,3.12,3.13\end{array}$ \\
\hline Walls & $q=U \times A \times C L T D$ & $\begin{array}{l}\text { U values from Tables 3.1-3.4, A3.1 and A3.2 } \\
\text { Area calculated from plans } \\
\text { Cooling Load Temperature Difference (CLTD) } \\
\text { rom tables 3.8, 3.12, 3.13 }\end{array}$ \\
\hline Glass & $q=U \times A \times C L T D$ & $\begin{array}{l}\text { U values from Tables 3.1-3.4, A3.1 and A3.2 } \\
\text { Area calculated from plans } \\
\text { Cooling Load Temperature Difference (CLTD) } \\
\text { rom tables } 3.23\end{array}$ \\
\hline Solar & $q=A \times S C \times S H G F \times C L F$ & $\begin{array}{l}\text { Net glass area calculated from plans } \\
\text { Shading coefficients from tables } 3.17-3.22 \\
\text { Max solar heat gain from tables } 3.25,3.26 \\
\text { CLF values from tables } 3.27,3.28\end{array}$ \\
\hline Partitions, Ceilings, Floors & $q=U \times A \times T D$ & $\begin{array}{l}\text { U values from Table } 3.1-3.5 \\
\text { Areas calculated from plans } \\
\text { Calculated Design Temperature Difference values }\end{array}$ \\
\hline Internal & $q=I N P U T \times C L F$ & $\begin{array}{l}\text { Type of Fixture, Installation, Air Supply } \\
\text { and Return and Room Furnishings and } \\
\text { Construction-Tables } 4.2 \text { and } 4.3 \\
\text { Cooling Load Factor Based on Total Hours of } \\
\text { Operation and Time -Table } 4.4\end{array}$ \\
\hline $\begin{array}{l}\text { Sensible } \\
\text { Latent }\end{array}$ & $\begin{array}{c}q_{s}=\text { No. } \times \text { Sens. H.G. } \times \text { CLF } \\
q_{I}=\text { No. } \times \text { Lat. H.G. }\end{array}$ & $\begin{array}{l}\text { Sensible Heat Gain from Occupants-Table } 4.5 \\
\text { Cooling Load Factor (or People-Based on Duration } \\
\text { of Occupancy and Time } \\
\text { Sensible from Entry-Table } 4.6 \\
\text { Latent Heat Gain from Occupants-Table } 4.5\end{array}$ \\
\hline Cooling Load Source & Equation & References, Table, Description \\
\hline $\begin{array}{cc}\text { Appliances } & \\
& \text { Sensible } \\
& \text { Latent }\end{array}$ & $\begin{array}{c}q_{s}=\text { HEAT GAIN } \times \text { CLF } \\
q_{1}=\text { HEAT GAIN }\end{array}$ & $\begin{array}{l}\text { Recommended Rate of Heat Gain-Sensible Heat- } \\
\text { Tables } 4.8 \text { and } 4.9 \\
q_{1} \text { Equal to Zero When Hood is Used Over } \\
\text { Appliances }\end{array}$ \\
\hline Power & $q=H E A T G A I N \times C L F$ & $\begin{array}{l}\text { Manufacturer's Data or Tables } 4.12 \text { and } 4.13 \\
\text { Table } 4.11 \text { or CLF }=1.0 \text { if cooling system is not } \\
\text { operated continuously }\end{array}$ \\
\hline
\end{tabular}




\begin{tabular}{|c|c|c|}
\hline $\begin{array}{c}\text { Ventilation \& Infiltration Air } \\
\text { Sensible } \\
\text { Latent } \\
\text { Total }\end{array}$ & $\begin{array}{c}q_{s}=1.10 \times C F M \times \Delta t \\
q_{1}=4840 \times C F M \times \Delta W \\
q_{1}=4.5 \times C F M \times \Delta h\end{array}$ & $\begin{array}{l}\text { Ventilation and Infiltration Air, Standard CFM- } \\
\text { Chapter } 5 \\
\text { Inside-Outside Air Temperature Difference, deg } \\
\text { F-Table } 2.1 \\
\text { Inside-Outside Air Humidity Ratio Difference Dry } \\
\text { Air-Tables } 2.1 \text { and } 2.3 \\
\text { Inside-Outside Air Enthalpy Difference, Btu/lb of } \\
\text { Dry Air-Psychrometric Chart }\end{array}$ \\
\hline Adjustment Factor & $F_{c}=l-0.02 K_{l}$ & $\begin{array}{l}\text { Fraction of Input Energy Lost to the } \\
\text { Surroundings; Applied to all External and } \\
\text { Internal Loads Except Ventilation and Infiltration } \\
\text { Air. } \\
K_{l}=\text { sum of U x A for all exterior wall surfaces } \\
\text { and then divided by length of exterior wall }\end{array}$ \\
\hline
\end{tabular}

The cooling loads are calculated to analyze if the HVAC equipment has the appropriate capacity to remove heat from the room. The next step in the research is to determine the cooling loads using experimental data. For the experimental purposes of this research, four major parameters were measured which include

- Solar transference (due to temperature difference);

- Air change load (infiltration or exfiltration);

- Machine load (heat dissipation via equipment);

- Heat dissipation from living organisms

A digital thermo-anemometer and a laser temperature-reading gun are used to determine CFM rates, drybulb room temperatures, as well as air velocity. Each diffuser in the room was checked to obtain the average CFM rates. In order to safely reach diffuser heights of over $15 \mathrm{ft}$., a multifunctional holding frame was designed and manufactured to attach the thermo-anemometer. Simple materials like a rolling bar, wooden blocks and $\operatorname{Velcro}^{\odot}$ tapes were used to create a support for the measuring device.

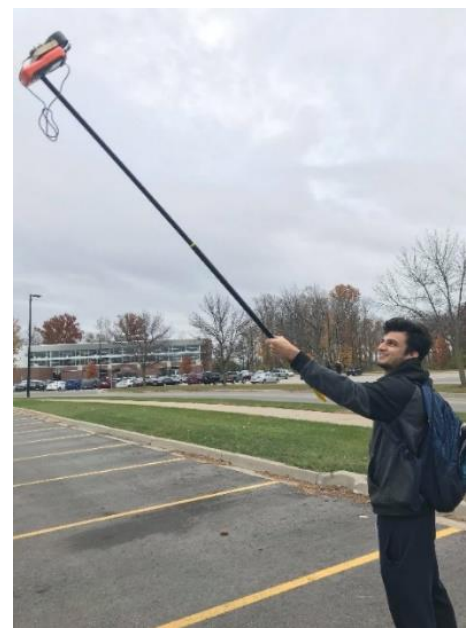

Fig. 1 Thermo-anemometer holding frame for far-reaching positioned vents

Figure 1 shows how the device was set up to measure CFM rates from the HVAC diffusers, positioned between $10 \mathrm{ft}-15 \mathrm{ft}$ above ground. The device successfully provided both convenience and safety in data collection.

\section{RESULTS AND DISCUSSION}

Design of cooling loads are based on the assumption of steady periodic conditions i.e., the design day's weather, occupancy, and heat transfer rates are identical to those for preceding days such that the loads repeat on an identical $24 \mathrm{~h}$ cycle.

The theoretical calculations and experimental results were conducted in classrooms, offices, computer labs and machine labs. Majority of the cold air is being transferred to the occupants and equipment in the classroom. 
The equipment in the classroom are a computer, monitor, projector, and router. The window, wall, roof, floor, and solar cooling loads are calculated from building specifications. For the classrooms, the cooling load was calculated for an occupancy of 36 people per classroom. In offices, maximum cold air is transferred to the equipment. The equipment in the offices are a computer, monitor, laptop, and printer. For the offices, the cooling load was calculated for an occupancy of 2 people per office. For the computer labs, the cooling load was calculated for an occupancy of 36 people per computer lab. The equipment in the computer lab are 24 computers, 24 monitors, router, and 2 printers. The equipment in the machine shop are a variety of machining equipment including microwave, mini fridge, plasma cutter, craftsman grinder, TIG 200 welder. The cooling load was calculated for an occupancy of 10 people in machine shops.

7 classrooms, 4 computer labs, 24 offices, and 3 machine labs were examined in the research.

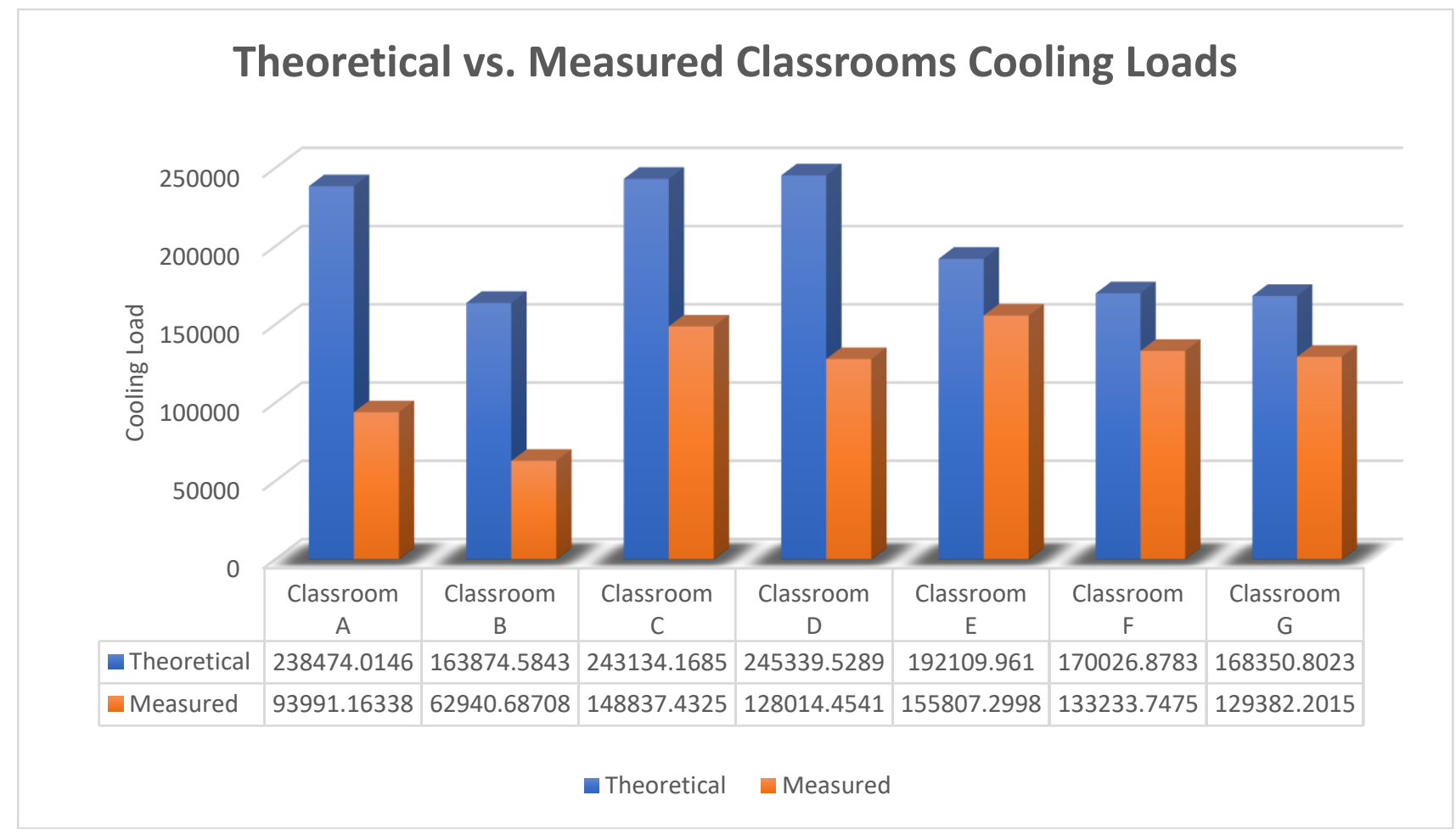

Fig. 2 Theoretical vs Measured CFM Values of Different Classrooms

The histogram from Figures 2-4 shows that the theoretical values in the different rooms do not match with experimental data. The machine labs and offices were observed to have adequate flow rates to sustain desirable temperatures whereas classrooms and computer labs have insufficient cooling loads. The occupancy rates are higher for classrooms and computer labs when compared to office rooms and machine lab's occupancy rates. The uncertainty in the results were expected because this research was conducted mainly to provide inconsistent data in different rooms to the building maintenance department. 


\section{Theoretical vs. Measured Computer Labs Cooling Loads}

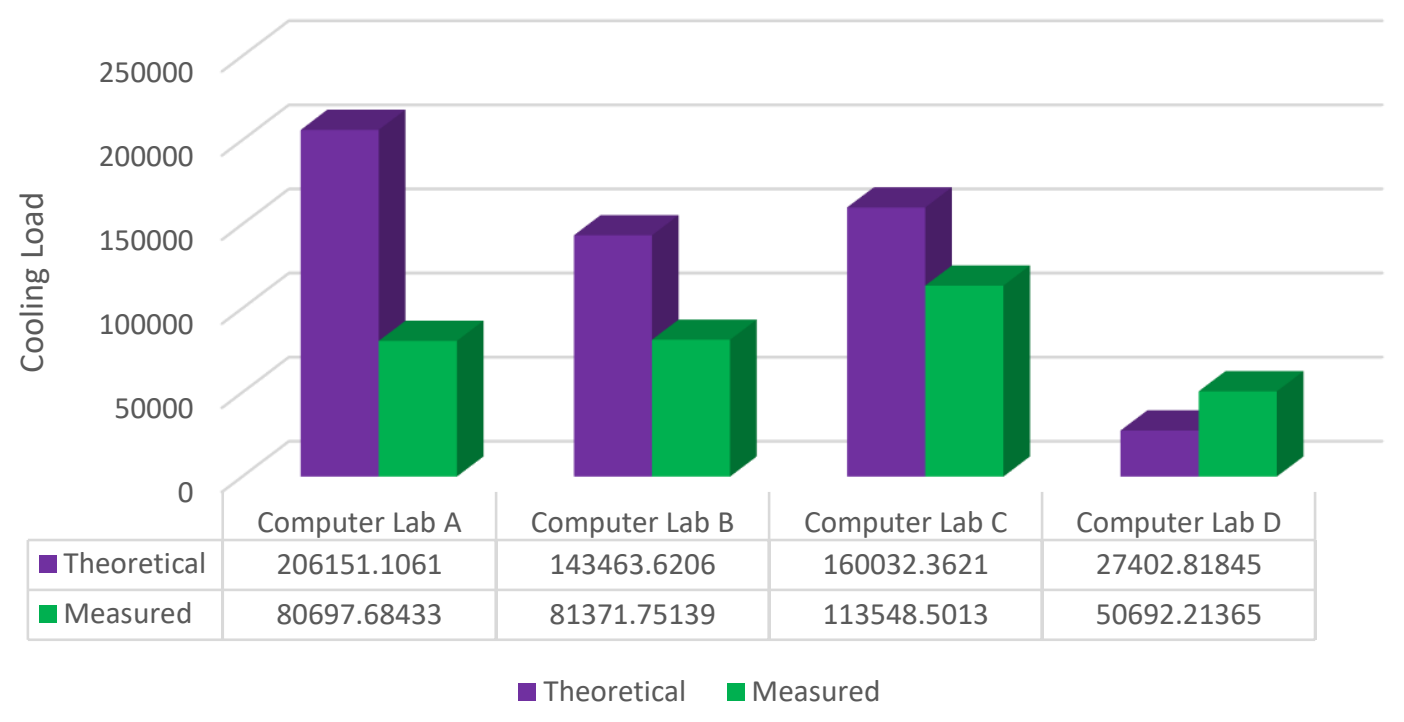

Fig. 3 Theoretical vs Measured CFM Values of Different Computer Labs

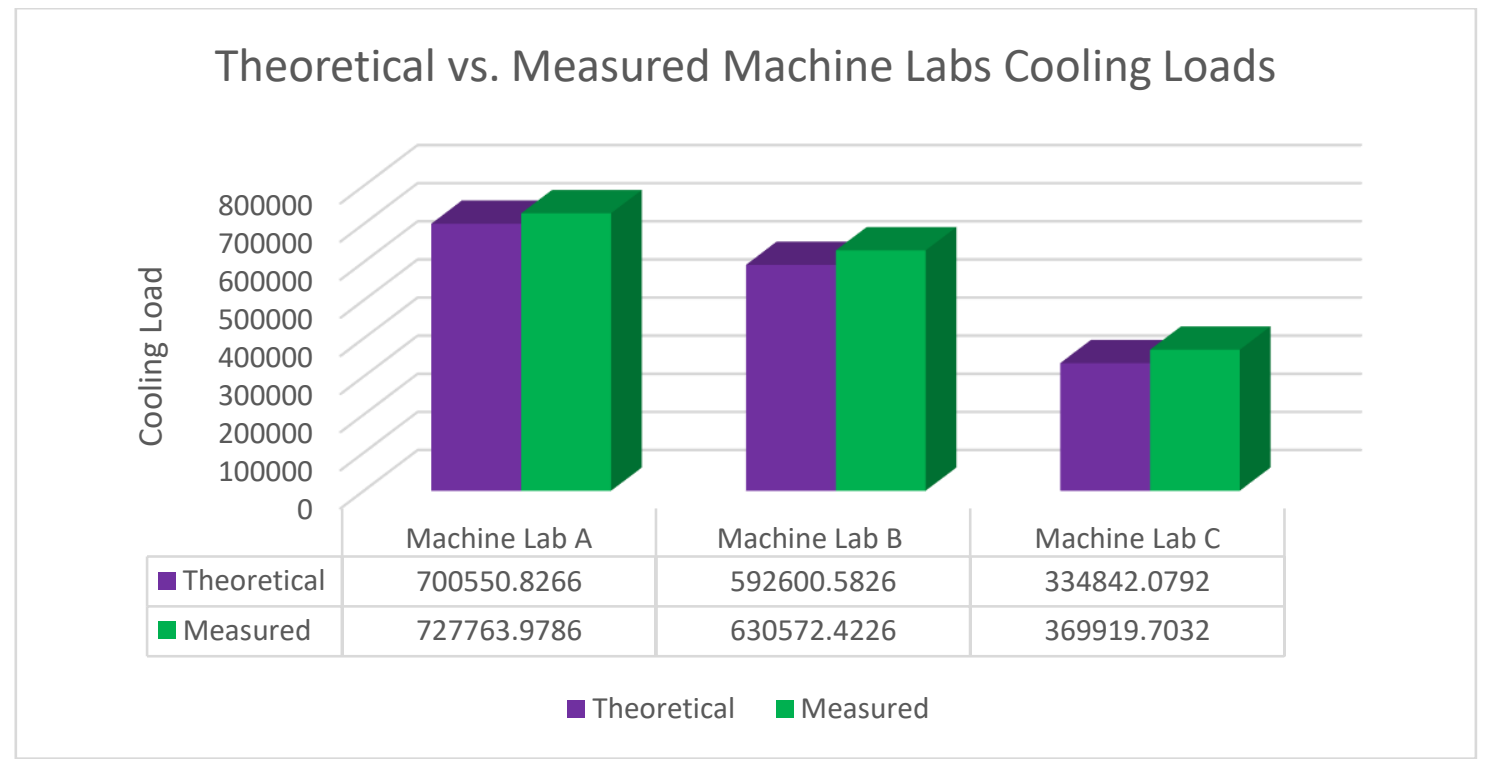

Fig. 4 Theoretical vs Measured CFM Values of Different Machine Lab

The study analyzed three types of cooling loads: total cooling load $q, q s$ is the sensible cooling load which is related to changes in temperature of a gas or object with no change in phase, and $q l$ is the latent cooling load which is related to changes in phase between liquids, gases, and solids ${ }^{[9]}$. Under further analysis, the measured and calculated CFM values were compared to determine if the measured CFM values are up to standard. The calculated CFM values are a standard of 15 CFM per person for all rooms in the multistory educational building. 
Table 3 Classroom Theoretical \& Measured Comparisons

\begin{tabular}{|l|r|r|r|}
\hline \multicolumn{5}{|c|}{ Classroom } \\
\hline CFM & Theoretical & Measured & Error (\%) \\
\hline$q$ & 82134 & 61727.73 & 24.84 \\
\hline$q s$ & 38095.2 & 28630.42 & 24.84 \\
\hline$q l$ & 27860.98 & 20938.9 & 24.84 \\
\hline
\end{tabular}

Table 4 Computer Lab Theoretical \& Measured Comparisons

\begin{tabular}{|l|r|r|r|}
\hline \multicolumn{5}{|c|}{ Computer Lab } \\
\hline CFM & Theoretical & \multicolumn{1}{|c|}{ Measured } & Error (\%) \\
\hline$q$ & 57037.5 & 22600.01 & 60.37 \\
\hline$q s$ & 26455 & 10482.28 & 60.37 \\
\hline$q l$ & 19347.9 & 7666.23 & 60.37 \\
\hline$q l$ & 7739.16 & 14883 & 92.30 \\
\hline
\end{tabular}

The measured CFM per person values of the classroom, office, computer lab, and machine shop A were approximately $9,165,5$, and 25 respectively. Tables 3 and 4 shows that the HVAC systems does not supply enough airflow to the classrooms and computer labs, causing an error of $24 \%$ and $60 \%$ respectively. The error is caused by the increased number of occupancies in those rooms over the years. In contrary, the HVAC system is supplying an abundance of air flow to the offices and the machine lab B. This generous amount of excess air is due to the high ceilings and adequate ventilation for the machines shop and small office sizes.

This shows the inconsistencies in HVAC system in the multi-story educational building which causes discomfort in the occupants. The improvements that can be done to minimize the difference in CFM values would be to check the HVAC system and make sure that it can supply enough air to a large multi-story educational building with full class sizes.

\section{CONCLUSIONS}

Cooling load data error obtained from classrooms and computer labs are due to the inability to maintain the air flow rates by the HVAC system. The air flow supply should be increased by $60 \%$ to meet the air flow requirements in classrooms. The supplied rate is very low and not up to the building code standards. This could result in tiredness and increased level of heat in the rooms at higher occupancy rates. Overall, the building requires modifications in air supply to maintain air quality.

\section{NOMENCLATURE}

\begin{tabular}{|c|c|c|c|c|}
\hline $\mathrm{U}$ & $\begin{array}{l}\text { Design Heat } \\
\text { Transfer Coefficient }\end{array}$ & $\left(\mathrm{Btu} / \mathrm{hr} . \mathrm{ft}^{2} . \circ \mathrm{F}\right)$ & CLF & $\begin{array}{l}\text { Cooling Load } \\
\text { Factor }\end{array}$ \\
\hline A & $\begin{array}{l}\text { Areas calculated } \\
\text { from plans }\end{array}$ & $\left(\mathrm{ft}^{2}\right)$ & TD & $\begin{array}{l}\text { Temperature } \\
\text { Difference }\end{array}$ \\
\hline CLTD & $\begin{array}{l}\text { Cooling Load } \\
\text { Temperature } \\
\text { Difference }\end{array}$ & & CFM & $\begin{array}{l}\text { Volumetric } \\
\text { Flow Rate }\end{array}$ \\
\hline $\mathrm{SC}$ & Shading Coefficients & & INPUT & $\begin{array}{c}\text { Input Rating } \\
\text { from Electrical } \\
\text { Plans }\end{array}$ \\
\hline
\end{tabular}




\begin{tabular}{|c|c|c|c|c|c|}
\hline SHGF & $\begin{array}{l}\text { Maximum Solar } \\
\text { Heat Gain Factor }\end{array}$ & $\left(\mathrm{Btu} / \mathrm{hr} . \mathrm{ft}^{2} . \circ \mathrm{F}\right)$ & Sens. H.G. & $\begin{array}{c}\text { Sensible Heat } \\
\text { Gain from } \\
\text { Occupants }\end{array}$ & (Btu/hr) \\
\hline$\Delta \mathrm{t}$ & $\begin{array}{l}\text { Inside-Outside Air } \\
\text { Temperature } \\
\text { Difference }\end{array}$ & & Lat H.G. & $\begin{array}{l}\text { Latent Heat } \\
\text { Gain from } \\
\text { Occupants }\end{array}$ & (Btu/hr) \\
\hline$\Delta \mathrm{W}$ & $\begin{array}{c}\text { Inside-Outside Air } \\
\text { Humidity Ratio } \\
\text { Difference }\end{array}$ & & HEAT GAIN & $\begin{array}{c}\text { Rate of Heat } \\
\text { Gain-Sensible } \\
\text { Heat }\end{array}$ & \\
\hline$\Delta \mathrm{h}$ & $\begin{array}{l}\text { Inside-Outside Air } \\
\text { Enthalpy Difference }\end{array}$ & & $\mathrm{F}_{\mathrm{c}}$ & $\begin{array}{l}\text { Fraction of } \\
\text { Input Energy } \\
\text { Lost to the } \\
\text { Surroundings }\end{array}$ & \\
\hline $\mathrm{K}_{1}$ & $\begin{array}{c}\text { Sum of } \boldsymbol{U} \times \boldsymbol{A} \text { for all } \\
\text { exterior wall } \\
\text { surfaces }\end{array}$ & & & & \\
\hline
\end{tabular}

\section{REFERENCES}

[1] Kumar, S., (n.d.). Cooling Load Estimation for a Multi-story office building. Department of Mechanical Engineering, National Institute of Technology. Journal Paper, pages 1-80.

[2] Elhelw, M. Analysis of energy management for heating, ventilating and air-conditioning systems. Mechanical Engineering Department, Alexandria University. Alexandria Engineering Journal, 18 February 2016.

[3] Alghoul, S. K., Rijabo, H. G., Mashena. M. E. Energy consumption in buildings: A correlation for the influence of window to wall ratio and window orientation in Tripoli, Libya. Department of Mechanical and Industrial Engineering, University of Tripoli. Journal of Building Engineering, 2017

[4] Allouhi, A., El Fouih, Y., Kousksou, T., Jamil, A., Zeraouli, Y., Mourad, Y. Energy consumption and efficiency in buildings: current status and future trends. Journal of Cleaner Production, 17 June 2015.

[5] Huang, J., Hanford, J., Yang, F. Residential Heating and Cooling Loads Component Analysis. Building Technologies Department, Lawrence Berkeley National Laboratory, University of California, Berkeley. November 1999

[6] Suqian, Y., Jiaping, L., Xiangrong, G., Xiang, H. The Research of Cooling Load and Cooling Capacity Calculation Methods of Spinning Workshop. Procedia Environmental Sciences Journal. Elsevier Ltd., 2011.

[7] American Society of Heating, Refrigerating and Air-Conditioning Engineers (ASHRAE). Cooling and Heating Load Calculations Manual. Contract No. H-2303 for the U.S. Department of Housing \& Urban Development. Retrieved from: https://www.hud.gov/sites/documents/DOC_10603.PDF

[8] Spitler, J.D., F.C. McQuiston, K. Lindsey. The CLTD/SCL/CLF Cooling Load Calculation Method, ASHRAE Transactions. 99(1): 183-192. 1993

[9] NC State University. (n.d.). Latent and Sensible Heat. Retrieved June 18, 2019, from: https://climate.ncsu.edu/edu/Heat 